\title{
Tourette-like Syndrome Following Low Dose Short-term Neuroleptic Treatment
}

\author{
Samarthji Lal and Esam AlAnsari
}

\begin{abstract}
A Tourette-like syndrome (TLS) may occur after long-term neuroleptic treatment. A review of 11 cases reported in the literature is given. We describe the onset of a TLS in a 13-year old boy with childhood schizophrenia after short term, low-dose treatment with thioridazine. The syndrome resolved 5 months after neuroleptic withdrawal. Subsequent exposure to neuroleptics (mainly perphenazine) induced a recurrence of motor tics and involuntary vocalizations which resolved on drug discontinuation. Awareness that neuroleptics may induce a TLS may lead to prompt recognition and avoidance of labelling the manifestations as symptoms of the underlying psychosis or attention-seeking behaviour.
\end{abstract}

\begin{abstract}
RÉSUMÉ: Une syndrome analogue à ce de Gilles de la Tourette suivant le traitement prolongé par des neuroleptiques Un syndrome analogue au syndrome de Gilles de la Tourette peut survenir à la suite d'un traitement prolongé par les neuroleptiques. Nous faisons une revue de 11 cas rapportés dans la littérature et nous décrivons le cas d'un jeune garcon de 13 ans souffrant de schizophrénie de l'enfance ayant présenté un tel syndrome après un traitement à la thioridazine à faible dose sur une courte période de temps. Le syndrome s'est dissipé, 5 mois après le retrait du neuroleptique. L'exposition subséquente à des neuroleptiques (surtout à la perphénazine), provoqua une réapparition des tics moteurs et des vocalisations involontaires qui disparurent à l'arrêt de la thérapie. La connaissance du fait que les neuroleptiques peuvent induire un syndrome analogue au Gilles de la Tourette peut conduire à un diagnostic rapide et éviter que ces manifestations soient étiquettées comme des symptomes de la psychose sous-jacente ou comme un comportement visant à attirer l'attention.

Can. J. Neurol. Sci. 1986: 13:125-128
\end{abstract}

Tardive dyskinesia (TD) is an involuntary movement disorder which develops following exposure to chronic neuroleptic treatment.' The range of movements that may occur is quite large. 'The most common manifestations of TD consist of choreic movements involving the face, mouth and tongue (oral TD). Occasionally, dystonic features predominate (tardive dystonia) ${ }^{2}$ and less commonly, symptoms of respiratory involvement (respiratory TD) are pre-eminent. ${ }^{3}$ In recent years a form of TD designated as Tourette-like syndrome (TLS) has been identified in which the prominent involuntary movements consist of motor tics and vocalizations ${ }^{4-12}$. These latter two symptoms are characteristically found in Gilles de la Tourette syndrome (GTS). ${ }^{13}$ The underlying mechanism subserving the development of the various clinical patterns of TD including TLS is believed to be chemical denervation supersensitivity of dopamine receptors following chronic neuroleptic blockade. ${ }^{1,3.5}$ An enhancement of dopaminergic function may also play a role in the pathophysiology of GTS. ${ }^{13}$

The age of onset of TLS in published cases is 19 to 69 years and has developed after 2-20 years of exposure to major tranquillizers. We report on a case of neuroleptic-induced TLS first developing at the age of 13 following short term exposure to low doses of thioridazine and whose apparently bizarre clinical presentation was overlooked as a manifestation of the underlying psychopathology. In view of the rarity of neurolepticinduced TLS we also present a review of published cases.

\section{CASE RePORT}

A.A., an 18-year old male without family history of neurological or psychiatric illness was diagnosed as having childhood schizophrenia at the age of 10 . He was started on thioridazine (25-50 mg/day). After 2-3 months the drug was discontinued because of the development of involuntary movements (nature unknown). The movements gradually subsided over a period of several months. At the age of 13, because of deterioration in behaviour, thioridazine was again prescribed (25-50 $\mathrm{mg}$ /day). After 2-3 months he began to exhibit involuntary movements and to make inappropriate burping and whistling noises which were considered attention seeking behaviour. After being on thioridazine for $21 / 2$ years the drug was discontinued. One month later because of increasingly bizarre behaviour, he was hospitalized. The patient was first seen by us soon after admission. He appeared ill at ease, anxious and frightened. His eyes were constantly searching or scanning the environment. He showed repetitive semi-purposeful movements. Thus, he would reach out as if to scratch various parts of his body, particu-

From the Department of Psychiatry. Montreal General Hospital and Douglas Hospital. Montreal

Reprint requests to: S. Lal, M.D., Department of Psychiatry, Montreal General Hospital, 1650 Cedar Avenue, Montreal, P.Q. H3G 1A4 
larly the groin and upper legs or upper arm or touch the top of his head and frown. He showed jerky movements of head and neck and shrugging of the shoulders. He had grinding of the teeth. He showed eyeclosing tics, rapid rotation of the head, pursing of the lips and tongue-incheek motion. He made frequent repetitive spontaneous vocalizations consisting of grunting, barking, sniffing, coughing, whistling, throatclearing, spitting and guttural noises. Palilalia and echolalia were also noted. Guttering (coprolalia) was documented only during one of the ensuing interviews. The intensity of involuntary motor movements and vocal tics fluctuated as did the pitch of his voice. The movements could be voluntarily suppressed for up to 10-15 minutes. Anxiety increased the noises and movements. Speech was frequently irrelevant and incoherent. He laughed inappropriately. Aside from the abnormal movements and vocal tics, physical examination was normal. There was no evidence of an upper respiratory infection or carditis. Routine biochemical investigations including liver function tests, serum calcium, phosphorous, T4 and electrolytes were normal. Urinalysis and hemogram were normal. The antinuclear antibody test was negative. EKG was normal. Slit-lamp examination showed noevidence of Kayser-Fleischer rings. CAT scan showed minimal lateral ventricular asymmetry with the left larger than the right, but was otherwise unremarkable. A diagnosis of neuroleptic-induced TLS in a patient with childhood schizophrenia was made. The diagnosis led to considerable relief amongst the staff who had been overwhelmed by his clinical picture and had assumed his involuntary movements were manifestations of schizophrenia. Over a period of five months, off all medications, the involuntary movements and noises gradually remitted. Thirteen months later because of worsening of the psychosis, neuroleptics were reinstituted. Initially, chlorpromazine $50 \mathrm{mg} /$ day for one month and then perphenazine mainly in a dose of $4 \mathrm{mg} /$ day was given. When seen 8 months after reinstitution of neuroleptics, he was free of both involuntary movements and vocal tics. When examined one month later while still on perphenazine he showed infrequent facial tics and an oral dyskinesia with episodic tongue protrusion. Occasional whistling noises were present. When asked to walk around in circles the whistling noises became repetitive and loud. As soon as he stopped walking the whistling subsided. Speech remained irrelevant and incoherent and affect inappropriate. He was next seen seven months later after he had been off all neuroleptics for five months. At this time there was no evidence of a movement disorder or abnormal vocalizations.

\section{Discussion}

The criteria for GTS according to the Diagnostic and Statistical Manual of Mental Disorders III (1980) ${ }^{14}$ are (a) age of onset between $2-15 \mathrm{yrs}$; (b) presence of recurrent involuntary, repetitive, rapid, purposeless motor movements involving multiple muscle groups (c) multiple vocal tics (d) ability to suppress movements voluntarily for minutes to hours (e) variation in intensity of the symptoms over weeks or months and (f) duration of more than one year. The involuntary movements described above are usually referred to as tics. Adult onset cases of GTS have also been described. ${ }^{15.16}$ Confirmatory, but not essential, symptoms for the diagnosis of GTS include coprolalia, copropraxia, echolalia, echopraxia and palilalia. ${ }^{13}$ In our review of the literature we came across 11 cases which were reported as having a TLS secondary to chronic neuroleptic therapy (Table 1). In two of the patients described by Fog and associates ${ }^{7.8}$ (no. 6 and 7 , Table 1) tics were absent or not well documented so that the appropriateness of the designation TLS is questionable. The remaining nine cases had symptoms considered as motor tics as well as vocal tics. The use of the term 'tic-like' by several of the authors emphasizes the problem in categorizing involuntary movements. Probably a variable degree of arbitrariness has been used in designating an abnormal movement as a tic. Some of the patients showed coprolalia, echolalia or palilalia. Interestingly, four of the patients had bruxism. Though teethgrinding may occur in GTS ${ }^{17}$ this symptom has not been emphasized in the literature.
Studies conducted in a single case of TLS reported by Stahl ${ }^{9}$ showed worsening with amphetamine and suppression with physostigmine or brief treatment with haloperidol. Similar pharmacological responses are noted with the more typical symptoms of TD ${ }^{18.19}$ and GTS. ${ }^{13}$ In one of the patients described by Fog and associates ${ }^{8}$ improvement followed the anticholinergic agent biperidene. In general TD symptoms (and symptoms of GTS) worsen or are unchanged after anticholinergic treatment though improvement has also been noted in a subset of TD patients. ${ }^{19}$ Pharmacological observations and the relationship of TLS to neuroleptic exposure, worsening on neuroleptic discontinuation and suppression with neuroleptics suggest that TLS is a variant of TD and related to dopamine receptor supersensitivity. ${ }^{9}$ The coexistence of symptoms of TD and TLS in the same patient also suggests a common pathophysiology. The similarity of symptoms and of drug responses point to a common mechanism underlying TLS and GTS.

Our patient first developed vocal tics when he was 13 years old. This age of onset might suggest that he was suffering from GTS rather than TLS. However, the onset of symptoms after initiation of neuroleptic therapy, the marked worsening on neuroleptic withdrawal, complete resolution over a period of five months off medication, maintenance of remission over a period of 21 months, recurrence of motor and vocal tics with reintroduction of major tranquillizers and subsequent resolution with drug discontinuation, suggest that his symptoms were directly related to neuroleptic exposure. Also, it would be rare indeed if the patient had both schizophrenia and GTS. ${ }^{13}$ Spontaneous remission in GTS has been described ${ }^{20}$ but this must be quite rare as Shapiro et al $^{13}$ have considered as one of the criteria for GTS the fact that the condition is life-long and chronic. The temporal relationship between neuroleptic treatment and clinical symptoms make it unlikely that spontaneous remission and exacerbation occurred in our patient independent of major tranquillizer therapy. Semi-purposeful movements (chorea) are described in Syndenham's chorea and such symptoms may occur in the absence of other manifestations of rheumatic fever and may last up to two years and recur. ${ }^{21}$ However, vocal tics are not a feature of this condition so that it is unlikely that our patient had Syndenham's chorea. There was no history in our patient of exposure to drugs such as L-dopa, ${ }^{22}$ methylphenidate, ${ }^{23}$ amphetamine,${ }^{24}$ pemoline ${ }^{25}$ or carbamazepine $^{26}$ which may also induce a TLS, or to other agents ${ }^{27.28}$ known to induce a dyskinesia.

In our patient involuntary movements and vocal tics developed after only 2-3 months of exposure to a relatively small dose of a single neuroleptic, namely, thioridazine (25-50 mg/day). During his first exposure to thioridazine $(25-50 \mathrm{mg} /$ day $)$ at the age of 10 , he had also developed involuntary movements after 2-3 months which suggest a predisposition to neuroleptic-induced dyskinesia. Prompt discontinuation may have prevented the onset of vocal tics at that time, or, they may have been overlooked. It has been suggested that thioridazine is less likely to induce TD than other neuroleptics. ${ }^{29}$ Our case suggests that thioridazine is not exempt from inducing a TLS even after low dose short-term treatment. The recurrence in our patient of symptoms of TLS following administration of other neuroleptics (mainly perphenazine $4 \mathrm{mg} /$ day) over a period of nine months suggests a susceptibility to neuroleptics in general.

The wide variety of stereotypes and mannerisms seen in schizophrenia and infantile autism, conditions for which neuro- 


\begin{tabular}{|c|c|c|c|c|c|c|c|c|}
\hline \multirow[b]{3}{*}{ No. } & \multirow[b]{3}{*}{$\begin{array}{c}\text { Sex \& } \\
\text { Diagnosis }\end{array}$} & \multirow[b]{3}{*}{$\begin{array}{c}\text { Age of } \\
\text { Onset }\end{array}$} & \multirow[b]{3}{*}{$\begin{array}{c}\text { NL } \\
\text { Duration }\end{array}$} & \multicolumn{3}{|c|}{ Symptoms } & \multirow[b]{3}{*}{ Outcome } & \multirow[b]{3}{*}{ Reference } \\
\hline & & & & \multirow[b]{2}{*}{$\begin{array}{l}\text { Prior } \\
\text { to NL }\end{array}$} & \multicolumn{2}{|c|}{ Following NL } & & \\
\hline & & & & & $\begin{array}{l}\text { Involuntary } \\
\text { Movements }\end{array}$ & $\begin{array}{l}\text { Involuntary } \\
\text { Vocalizations }\end{array}$ & & \\
\hline 1 & F Schiz. & $\begin{array}{l}24 \mathrm{y} .<1 \mathrm{mo} \\
\text { after } \\
\mathrm{NL} \mathrm{D/C}\end{array}$ & $\begin{array}{l}\text { Chlorpromazine } \\
6 \mathrm{y} .\end{array}$ & None & $\begin{array}{l}\text { Tic-like movements of } \\
\text { arms, neck and face; } \\
\text { bruxism; arm dystonia. }\end{array}$ & $\begin{array}{l}\text { Barking } \\
\text { Clicking }\end{array}$ & $\begin{array}{l}\text { Improved with } \\
\text { haloperidol } \\
30 \mathrm{mg} / \mathrm{d}\end{array}$ & 4 \\
\hline 2 & $\begin{array}{l}\text { F } \\
\text { 'Anxiety' }\end{array}$ & $\begin{array}{l}69 \mathrm{y} . \\
\text { after NL D/C }\end{array}$ & $\begin{array}{l}\text { Trifluoperazine } \\
(4-6 \mathrm{mg} / \mathrm{d}) 20 \mathrm{y} .\end{array}$ & None & $\begin{array}{l}\text { Lingual-facial-buccal } \\
\text { dyskinesia; facial tics; } \\
\text { bruxism. }\end{array}$ & $\begin{array}{l}\text { Grunting } \\
\text { Stereotyped } \\
\text { counting; } \\
\text { Echolalia. }\end{array}$ & $\begin{array}{l}\text { No change over } \\
2 \text { y. after } N L D / C\end{array}$ & 5 \\
\hline 3 & $\begin{array}{l}\text { F Par. } \\
\text { Schiz. }\end{array}$ & $\begin{array}{l}32 \mathrm{y} . \\
\text { while on NL }\end{array}$ & $\begin{array}{l}\text { Misc. NL } \\
9 y .\end{array}$ & None & $\begin{array}{l}\text { Tic-like movements of } \\
\text { face; blepharospasm; } \\
\text { bruxism. }\end{array}$ & $\begin{array}{l}\text { Grunting } \\
\text { Barking } \\
\text { Coprolalia } \\
\text { Echolalia } \\
\text { Palilalia }\end{array}$ & & 5 \\
\hline 4 & F Schiz. & $\begin{array}{l}19 \mathrm{y} . \\
\text { while on NL }\end{array}$ & $\begin{array}{l}\text { Misc. NL } \\
6 \mathrm{y} .\end{array}$ & None & $\begin{array}{l}\text { Grimacing; eye } \\
\text { blinking }\end{array}$ & $\begin{array}{l}\text { Hissing } \\
\text { Inarticulate } \\
\quad \text { noises } \\
\text { Coprolalia }\end{array}$ & $\begin{array}{l}\text { lmproved with } \\
\text { haloperidol } \\
20 \mathrm{mg} / \mathrm{d}\end{array}$ & 6 \\
\hline 5 & $\begin{array}{l}\text { M Simp. } \\
\text { Schiz. }\end{array}$ & $\begin{array}{l}20 \mathrm{y} . \\
\text { after NL D/C }\end{array}$ & $\begin{array}{l}\text { Haloperidol } \\
(2-10 \mathrm{mg} / \mathrm{d}) \\
2 \mathrm{y}\end{array}$ & None & $\begin{array}{l}\text { Tics of head and } \\
\text { body. }\end{array}$ & Grunting & $\begin{array}{l}\text { Improved with } \\
\text { haloperidol or } \\
\text { biperidene. } \\
\text { Pimozide } \pm \\
\text { tetrabenazine no } \\
\text { effect }\end{array}$ & 8 \\
\hline 6 & $\begin{array}{l}\text { M Par. } \\
\text { Schiz. }\end{array}$ & $\begin{array}{l}54 \mathrm{y} . \\
\text { while on NL }\end{array}$ & $\begin{array}{l}\text { Misc. NL } \\
14 \mathrm{y} .\end{array}$ & None & $\begin{array}{l}\text { (Spells of arm } \\
\text { movements; door } \\
\text { slamming) }\end{array}$ & $\begin{array}{l}\text { Echolalia } \\
\text { (Words, } \\
\text { shouting) }\end{array}$ & $\begin{array}{l}\text { lmproved with } \\
\text { pimozide }(6 \mathrm{mg} / \mathrm{d}) \\
\pm \text { tetrabenazine } \\
\text { or with } \\
\text { thioridazine }\end{array}$ & 8 \\
\hline 7 & $\begin{array}{l}\text { M Par. } \\
\text { Schiz. }\end{array}$ & $\begin{array}{l}50 \mathrm{y} . \\
\text { while on } \mathrm{NL}\end{array}$ & $\begin{array}{l}\text { Misc. NL } \\
8 \mathrm{y} .\end{array}$ & $\begin{array}{l}\text { Echo- } \\
\text { praxia }\end{array}$ & $\begin{array}{l}\text { Worsening of echo- } \\
\text { praxia; oral } \\
\text { dyskinesia. No tics. }\end{array}$ & $\begin{array}{l}\text { Howling } \\
\text { Echolalia }\end{array}$ & $\begin{array}{l}\text { Markedly } \\
\text { improved with } \\
\text { pimozide }(6 \mathrm{mg} / \mathrm{d}) \\
\text { or perphenazine. }\end{array}$ & 8 \\
\hline 8 & $\begin{array}{l}\text { M Inf. } \\
\text { Autism }\end{array}$ & $\begin{array}{l}26 \text { y. } \\
2-4 \text { wk. after } \\
\text { NL D/C }\end{array}$ & $\begin{array}{l}\text { Thioridazine } \\
\text { or chlorpromazine } \\
(200 \mathrm{mg} / \mathrm{d}) \\
13 \mathrm{y} .\end{array}$ & $\begin{array}{l}\text { Bizarre } \\
\text { sounds; } \\
\text { stereo- } \\
\text { typed } \\
\text { move- } \\
\text { ments }\end{array}$ & $\begin{array}{l}\text { Facial tics; involun- } \\
\text { tary limb movements; } \\
\text { tic-like movements of } \\
\text { neck, torso, abdomen, } \\
\text { diaphragm }\end{array}$ & $\begin{array}{l}\text { Grunting } \\
\text { Sniffing } \\
\text { Barking } \\
\text { Coprolalia }\end{array}$ & $\begin{array}{l}\text { No change over } \\
2 \text { y. after NL D/C }\end{array}$ & 9 \\
\hline 9 & $\mathbf{M}$ & $\begin{array}{l}65 \text { y. }>2 \text { mo. } \\
\text { after NL D/C }\end{array}$ & $\begin{array}{l}\text { Thioridazine } \\
\text { ( } 100 \mathrm{mg} / \mathrm{d} \times 4 \mathrm{y} .) \\
\text { Perphenazine } \\
(42 \mathrm{mg} / \mathrm{d} \times 2 \mathrm{y} .) \\
6 \mathrm{y} .\end{array}$ & None & $\begin{array}{l}\text { Oro-facial tic-like } \\
\text { movements }\end{array}$ & $\begin{array}{l}\text { Grunting } \\
\text { Barking }\end{array}$ & $\begin{array}{l}\text { Ceased } 6 \text { mos. } \\
\text { after NL D/CB }\end{array}$ & 10 \\
\hline 10 & F Schiz. & $\begin{array}{l}25 \mathrm{y} . \\
\text { while on NL }\end{array}$ & $\begin{array}{l}\text { Misc. NL } \\
3 \mathrm{y} .\end{array}$ & None & $\begin{array}{l}\text { Grimacing; blepharo- } \\
\text { spasm; bruxism; } \\
\text { snarling }\end{array}$ & $\begin{array}{l}\text { Grunting } \\
\text { Coprolalia }\end{array}$ & $\begin{array}{l}\text { Ceased } 4 \text { mos. } \\
\text { after } N L D / C\end{array}$ & 11 \\
\hline 11 & $\begin{array}{l}\text { M Inf. } \\
\text { Autism }\end{array}$ & $\begin{array}{l}27 \text { y. } 3 \text { wk. } \\
\text { after NL D/C }\end{array}$ & $\begin{array}{l}\text { Mainly thiori- } \\
\text { dazine }(800-1200 \\
\text { mg/d } \times 12 \text { y. }) \text {, then } \\
\text { chlorpromazine } \\
(2000 \mathrm{mg} / \mathrm{d} \times 3 \mathrm{y} .) \\
\text { then tapered } \\
19 \mathrm{y} \text {. }\end{array}$ & Rocking & $\begin{array}{l}\text { Truncal rocking; } \\
\text { choreo-athetoid } \\
\text { finger movements; } \\
\text { lip smacking and } \\
\text { licking; arm flapping; } \\
\text { head tilting and } \\
\text { shaking. }\end{array}$ & $\begin{array}{r}\text { Clicking } \\
\text { Gutteral } \\
\text { noises }\end{array}$ & $\begin{array}{l}\text { Improved with } \\
\text { haloperidol } 6 \mathrm{mg} / \mathrm{d} \\
\text { Relapse on } \\
\text { dose decrease. }\end{array}$ & 12 \\
\hline
\end{tabular}

\footnotetext{
" Par. Schiz. = paranoid schizophrenia; Simp. Schiz. = simple schizophrenia; Inf. Autism = infantile autism.

Patients No. 6 and 7 also had cortical atrophy; patient No. 7 had sclerotic plagues in the left caudate.

${ }^{b}$ Also on phenobarbital and phenytoin for epilepsy.

c $\mathrm{NL}$ D/C = neuroleptics discontinued.

${ }^{\mathrm{d}}$ Misc. $\mathrm{NL}=$ miscellaneous neuroleptics.

- Symptoms in parenthesis difficult to assess.

'Occasional diazepam and phenobarbital also received.

${ }^{8}$ Generalized tardive dyskinesia lasted two months after NL D/C and replaced by TLS which then resolved.

"Also on lithium $x 1$ year; no effect on TLS when lithium $D / C$.
} 
leptics are often prescribed, may make it difficult to diagnose a drug-induced movement disorder. ${ }^{1.30}$ In the patient reported by Pary ${ }^{6}$ as well as in our own case, the symptoms of TLS were mistaken as symptoms of the underlying psychosis. This problem in recognition may account for the apparent rarity of TLS recorded in the literature. In the patient described by Seeman et al " the patient's symptoms were interpreted as attention seeking behaviour. A similar interpretation was given in our patient.

The present case report emphasizes that a TLS may develop in early adoiescence even after low dose short-term exposure to neuroleptics. Awareness of this possibility should lead to prompt recognition and avoidance of inappropriate management.

\section{REFERENCES}

1. Marsden CD, Tarsy D and Baldessarini RJ. Spontaneous and drug-induced movement disorders in psychiatric patients. In: Psychiatric Aspects of Neurologic Disease, DF Benson and D Blumer, eds. Grune and Stratton, N.Y. 1975.

2. Tarsy D, Granacher R, Bralower M. Tardive dyskinesia in young adults. Am J Psychiat 1977: 134: 1032-1034.

3. Weiner WJ, Goetz CG, Nausieda PA. Klawans HL. Respiratory dyskinesias: extrapyramidal dysfunction and dyspnea. Ann Int Med 1978; 88: 327-331.

4. Klawans HL, Falk DK, Nausieda PA, Weiner WJ. Gilles de la Tourette syndrome after long term chlorpromazine therapy. Neurology 1978; 28: 1064-1068.

5. Klawans HL, Nausieda PA, Goetz CG, Tanner CM, Weiner WJ. Tourette-like symptoms following chronic neuroleptic therapy. Adv Neurol 1982; 35: 415-418.

6. Pary RJ. The 'psychotic curse'. Am J Psychiat 1979; 136: 715-716.

7. Fog R, Pakkenberg H.Theoretical and clinical aspects of the Tourette syndrome (chronic multiple tic). J Neural Transm Suppl 1980; 16: $211-215$.

8. Fog R, Pakkenberg H, Regeur L, Pakkenberg B. "Tardive" Tourette syndrome in relation to long-term neuroleptic treatment of multiple tics. Adv Neurol 1982; 35: 419-421.

9. Stahl SM. Tardive Tourette syndrome in an autistic patient after long-term neuroleptic administration. Am J Psychiat 1980; 137: 1267.1269.

- 10. DeVaugh-Geiss J. Tardive Tourette syndrome. Neurology 1980;30: 562.
11. Seeman MV, Patel J, Pyke J. Tardive dyskinesia with Tourette-like syndrome. J Clin Psychiat 1981; 42: 357-358.

12. Mueller J, Aminoff MJ. Tourette-like syndrome after long-term neuroleptic drug treatment. Brit J Psychiat 1982; 141: 191-193.

13. Shapiro AK, Shapiro ES, Brun RD, Sweet RD. Gilles de la Tourette syndrome. Raven Press, N.Y. 1978.

14. Diagnostic and Statistical Manual of Mental Disorders (III). American Psychiatric Association, Washington, D.C. 1980.

15. Marneros A. Adult onset of Tourette's syndrome: a case report. Am J Psychiat 1983; 140: 924-925.

16. Sutula T, Hobbs WR. Senite-onset vocal and motor tics. Arch Neurol 1983; 40: 825-826.

17. Waserman J, Lal S, Gauthier S. Gilles de la Tourette's syndrome in monozygotic twins. J Neurol Neurosurg Psychiat 1983;46:75-77.

18. Klawans HL, Weiner $W$. The effect of d-amphetamine on choreiform disorders. Neurology 1974; 24: 312-318.

19. Gerlach J, Reisby N, Randrup A. Dopaminergic hypersensitivity and cholinergic hypofunction in the pathophysiology of tardive dyskinesia. Psychopharmacologia 1974; 36: 21-35.

20. Fernando SJM. Six cases of Gilles de la Tourette's syndrome. Brit J Psychiat 1976; 128: 436-441.

21. Aron AM, Freeman JM, Carter S. The natural history of Sydenham's chorea. Am J Med 1965; 38: 83-95.

22. Klempel K. Gilles de la Tourette's syndrome induced by L-dopa. S Afr Med J 1974; 48: 1379-1380.

23. Golden GS. The effect of central nervous system stimulants on Tourette syndrome. Ann Neurol 1977; 2: 69-70.

24. Lowe TL, Cohen DJ, Detlor J, Krementizer MW, Shaywitz BA. Stimulant medications precipitate Tourette's syndrome. J Amer Med Assoc 1982; 247: 1729-1731.

25. Mitchell E, Mathews KL. Gilles de la Tourette's disorder associated with pemoline. Am J Psychiat 1980; 137: 1618-1619.

26. Neglia JP, Glaze DG, Zion TE. Tics and vocalizations in children with carbamazepine. Pediatrics 1984; 73: 841-844.

27. Kaplan SR, Murkofsky C. Oral-buccal dyskinesia symptoms associated with low dose benzodiazepine treatment. Am J Psychiat 1978; 135: 1558-1559.

28. Chadwick D, Reynolds EH, Marsden CD. Anticonvulsant induced dyskinesias. J Neurol Neurosurg Psychiat 1979; 39: 1210-1218.

29. Blowers AJ. Epidemiology of tardive dyskinesia in the elderly. Neuropharmacology $1981 ; 20: 1339-1340$.

30. Campbell M, Grega DM, Green WH, Bennett WG. Neurolepticinduced dyskinesias in children. Clin Neuropharmacol 1983; 6 : 207-222. 